IZA DP No. 7110

A Roadmap to Vocational Education and Training Systems Around the World

Werner Eichhorst

Núria Rodríguez-Planas

Ricarda Schmidl

Klaus F. Zimmermann

December 2012 


\title{
A Roadmap to Vocational Education and Training Systems Around the World
}

\author{
Werner Eichhorst
}

$I Z A$

\author{
Núria Rodríguez-Planas \\ $I Z A$ and IAE-CSIC \\ Ricarda Schmidl \\ $I Z A$
Klaus F. Zimmermann
IZA and Bonn University
Discussion Paper No. 7110
December 2012

\author{
IZA \\ P.O. Box 7240 \\ 53072 Bonn \\ Germany \\ Phone: +49-228-3894-0 \\ Fax: +49-228-3894-180 \\ E-mail: iza@iza.org
}

\begin{abstract}
Any opinions expressed here are those of the author(s) and not those of IZA. Research published in this series may include views on policy, but the institute itself takes no institutional policy positions. The IZA research network is committed to the IZA Guiding Principles of Research Integrity.

The Institute for the Study of Labor (IZA) in Bonn is a local and virtual international research center and a place of communication between science, politics and business. IZA is an independent nonprofit organization supported by Deutsche Post Foundation. The center is associated with the University of Bonn and offers a stimulating research environment through its international network, workshops and conferences, data service, project support, research visits and doctoral program. IZA engages in (i) original and internationally competitive research in all fields of labor economics, (ii) development of policy concepts, and (iii) dissemination of research results and concepts to the interested public.
\end{abstract}

IZA Discussion Papers often represent preliminary work and are circulated to encourage discussion. Citation of such a paper should account for its provisional character. A revised version may be available directly from the author. 
IZA Discussion Paper No. 7110

December 2012

\section{ABSTRACT}

\section{A Roadmap to Vocational Education and Training Systems Around the World*}

With young people among the big losers of the recent financial crisis, vocational education and training (VET) is often seen as the silver bullet to the problem of youth joblessness. This paper provides a better understanding of VET around the world, dealing with three types of vocational systems: school-based education, a dual system in which school-based education is combined with firm-based training, and informal training. We first explore the motivation for these different types of training, before summarizing the institutional evidence, highlighting the key elements of each training system and discussing its main implementation strengths and challenges. We subsequently review the evidence on the effectiveness of VET versus general education and between the three VET systems. There are clear indications that VET is a valued alternative beyond the core of general education, while the dual system tends to be more effective than school-based VET. Informal training is effective, however relatively little is known of its relative strengths compared with other forms of vocational education.

JEL Classification: J24, 125, O17

Keywords: vocational education and training, dual VET, informal training

Corresponding author:

Núria Rodríguez-Planas

Visiting Research Fellow

IZA

P.O. Box 7240

53072 Bonn

Germany

E-mail: rodriguez-planas@iza.org

\footnotetext{
This study is a condensed and revised version of a background paper to the 2013 World Development Report which was commissioned by the World Bank. The background paper can be found online at www.worldbank.org/wdr2013 and as IZA Discussion Paper No. 6890. We would like to thank all co-authors of this paper - Costanza Biavaschi, Corrado Giulietti, Michael Kendzia, Alexander Muravyev and Janneke Pieters - as well as World Bank colleagues for their input and support.
} 


\section{Introduction}

Unemployment rates among youths have soared since the Great Recession of 2008, doubling that of the adult population in many developed and developing countries. While many young people have responded to the sluggish labor market prospects by continuing tertiary education and investing in their human capital, others have all together withdrawn from education, training, and employment. The share of youths (aged 18 to 24) neither in employment nor education (NEET) in 2011 ranges from 4 percent (the Netherlands) to up to 20 percent (Italy and Greece) in Europe, 12 percent in Australia and New Zealand, and 15 percent in the US (OECD, 2012). Existing evidence from developing countries suggests that rates are even higher, with an average 20 percent of youths in NEET in Latin America (ILO 2010) and 25 percent in African countries (AfDB, OECD, UNDP and UNECA 2012).

Vocational education and training (VET) is frequently perceived as the solution to improving the opportunities of youths who lack the resources, skills or motivation to continue with higher education. ${ }^{1}$ Moreover, many argue that VET provides useful skills to prepare for youths' entry into the labor force and improve their chances of a successful professional career (Quintini and Martin 2006, OECD 2010a, Middleton et al. 1993). In particular, by aligning the initial education more closely to particular vocations and tasks demanded in the labor market, the problem of mismatch, often seen as a main source of the high degree of unemployment in developing countries, may be reduced (Almeida, Behrman, Robalino 2012). However, the relevance of VET varies significantly across clusters of countries around the world. As opposed to general education, VET is only a prominent part of secondary education in a number of mostly continental European and Scandinavian countries. VET around the world can be classified into three distinct systems: (i) school-based, (ii) a dual apprenticeship system combining school training with a firm-based approach, and (iii) informal-based. The focus of this paper is to understand the motivation behind each of these systems, assessing their strengths and challenges and reviewing the evidence under which conditions different VET systems best work. In addition, the paper reviews evidence in support of school-based VET versus general education, and compares the effectiveness between the three VET systems.

\footnotetext{
${ }^{1}$ In this article, we use the term "vocational education and training” (VET) to refer to qualifying education paths that provide individuals with occupations-specific knowledge and practical skills, independent of the place, content, and the provider of education. Sometimes it is also called TVET (technical and vocational education and training). The two terms are used interchangeably in the literature. Our focus is on the issue of initial VET, in contrast to vocation-specific education and training as part of life-long-learning (see Arulampalam et al. (2004) and Bassanini et al. (2005) for workplace training in Europe).
} 


\section{School-Based Vocational Education and Training}

The initial schooling system in most developed countries is characterized by the duality between general and vocational education. While the former aims to provide youths with general, often academically oriented, knowledge as the basis for further (higher) education and training, VET provides youths with practice-oriented knowledge and skills required in specific occupations. Most frequently, VET follows a formal curriculum that combines general and occupation-specific knowledge. Variation in types of school-based VET arise with respect to the academic level of vocational schooling-at the lower or upper secondary level; the places of learning-at general schools, and/or at specific training centers or colleges (for an overview in European countries, see CEDEFOP 2008). Consequently, VET is integrated in compulsory schooling as alternative to an academically-oriented schooling track, or as part of several post-compulsory education options. Similar to academic education, the skills provided by vocational schools are mostly general in the sense that they are transferable between employers (Becker 1964). However, there might be differences in the degree of transferability across occupations-while the VET system in some countries transmits skills that are not restricted to one particular occupation, in others it provides vocational schooling for specific types of occupations (Shavit and Müller 1998).

The supply of VET by the government through the educational system can be justified as a means to improve the opportunities of youths who lack the skills demanded in the labor market, or the ability or motivation to continue with higher education. Furthermore, individuals might prefer this option to academic education as it implies shorter investment of human capital and facilitates earlier entry into the labor market.

The vocational education system is less developed in developing countries, despite innumerous attempts to "vocationalize" the schooling systems based upon the European model. For instance, attempts to expand vocational schooling in Sub-Saharan Africa from the 1960s onwards failed due to structural dysfunctions of the local labor markets (Foster 1965; King and Martin 2002). As the private sector created insufficient labor demand and paid lower wages than the public sector, the incentives to invest in these non-academic, vocational skills were low. However, the massive reduction of the public sector during past decades and the expansion of formal educational attainment at the primary and secondary level have generated a huge young labor force equipped with basic skills yet unable to find a foothold in the local labor markets (Haltiwanger and Singh 1999). Consequently, many developing countries are seeking an educational strategy "beyond the basics" that aims to 
fully use the potential of these workers and prepare their workforce for the increasing competition of international markets (King, McGrath and Rose 2007). To achieve this, they have turned to revitalizing their VET system (King 2011), emphasizing the need for high quality vocational education.

In developing countries, the education of youths with practical oriented vocational skills is further considered a promising means to create flexible and self-responsible learning attitudes, which might hence better prepare youths for the requirements of the modern work place. Furthermore, given that poor skills and hence low productivity of firms is often seen as the reason for low levels of developments, the investment in vocational education is often justified as a means to promote a bottom-up labor market transformation. Therefore, the installment of an efficient vocational education system is conceived as an important pillar of the transformation into a knowledge-based economy.

Vocational education may also be the solution for low-ability individuals or low-motivated individuals for whom the costs of investing in general human capital are too high, or for youths who heavily discount the future. Many countries provide a vocational schooling option during compulsory schooling, perceived as an alternative for poor academically performing or at-risk youths (Neumann and Ziderman 1999), and a "safety net" for early school drop outs and those who are less academically inclined. The close link to work tasks and hands-on-practical experience should motivate practically-oriented youths to continue training and remain in school longer. Furthermore, the installation of a vocational education track during school has frequently been argued as reducing the influence of parental background on educational choices, thereby increase intergenerational mobility. Given that the educational decisions of youths are often linked to the educational-attainment level of their parents, participation in a vocational track might allow youths from a working-class background to pursue educational attainment beyond the compulsory level, hence increasing their chances of attaining skilled rather than unskilled employment (Shavit and Müller 1998). In most cases, participation in either vocational or academic courses during school is operationalized by tracking students into the two different education pathways. The benefits of such a tracking system are not clear, as leaving school with vocational qualification often translates into reduced options of further post-compulsory education, particularly of the academic type. The incentive effect of learning more practice-oriented skills might hence be mitigated by high costs of later switching to academic education. Although the technical possibility of transferring to academic education might exist, earlier tracking will lead to 
strongly divergent levels of skills and competences (Woessmann 2008). Furthermore, with the separation of high- and low-type students, VET might counteract the equalizing potential of vocational education (Shavit and Müller 2000). Given that only few youths practically manage to enter academic education after vocational schooling (Kogan 2008, Carrero 2006), the vocational schooling option is often perceived as a dead-end track and second-choice education in many countries, very lowly regarded by the population.

\section{Implementation Strengths and Challenges}

Despite many European countries maintain a large vocational schooling system as part of their upper secondary education, they generally differ with respect to how the vocational system is operated. Moreover, the lack of comparability across institutions makes it difficult to identify a "successful" system. Evidence available from cross-country comparisons in Europe and other countries that have attempted to implement a vocational schooling system points to several systematic elements of success, as described below (Woessmann 2008; CEDEFOP, 2008a, 2008b, Carrero 2006).

1. To ensure relevance of curricula, all stakeholders (government, employers, social partners, educational institutions) are involved in its development, with a clear assignment of responsibilities. However, the weight of the respective voices might differ across countries.

2. To maintain a close contact to the labor market, a system of continuous feedback from employers and private-sector institutions is required, which is particularly difficult to implement if employers have low levels of organization.

3. To ensure high-quality schooling, sufficient funding is required to guarantee the appropriate teaching material and the availability of well-trained teachers.

4. To incentivize training providers and create competition amongst training providers, a mix of public and private funding is required in addition to providing autonomy in teaching and staffing decisions.

5. To maintain a high level of training quality, a decentralized system of accreditation and quality assurance, as well as competition between training centers (such as output-based funding) is deemed crucial.

6. To limit the risk of establishing a dead-end vocational schooling track, the competences and qualifications acquired should be made comparable to those 
acquired in the academic tracks to promote possibilities of transfers between the two.

The practical implementation of school-based training is not easy, and we summarize the key challenges emerging with school-based VET in different countries accordingly, classified by their regional and institutional similarities.

Southern European Countries. Youths in Southern European countries such as Spain, Portugal, Italy, Greece as well as France face particular difficulties when trying to enter the labor market, with these long-standing problems aggravated by the recent economic crisis. Despite having above-average NEET rates, labor market entry is difficult for both low- and high-skilled young people. One major factor is the deep segmentation of the labor market between permanent and fixed-term contracts, which can be attributed to strict dismissal protection and largely liberalized temporary employment. In these countries, transition to a permanent position is difficult. Another issue is wage compression in low-skilled occupations by collective bargaining. For instance, collective bargaining in Spain, which is centralized at the province/industry level, sets "entry minimum wage" above the legal minimum wage, inflating the lower part of the wage distribution and resulting in relatively high earnings for young workers and those least qualified.

VET in these countries only plays a marginal role, and is largely school-based, with only 4 percent of those in vocational upper-secondary education in Spain combining school- and work-based training, in sharp contrast with the 74 percent share in Germany, where dual VET is most prominent (Cedefop 2010). The relatively marginal role of VET in these countries can be explained by a limited interest of employers in more formal VET (owing to the dual employment structure), and also by strong expectations of upward social mobility on behalf of young people and their families, thus creating strong preference in favor of academic training. Finally, the focus on subsidizing youth employment in these countries has backfired. Over the last 30 years, Spain has reduced employers' costs of hiring young workers via subsidies (contratos de aprendizaje, formación y en prácticas). Similarly, there has been a long tradition of subsidizing temporary employment and training contracts in both Italy and France. However, the effectiveness of these measures is questionable as explained by Felgueroso (2010) in Spain, Roger and Zamora (2011) in France, and Tattara and Valentini (2009) in Italy.

The Middle East and North Africa (MENA) countries. One of the main challenges in implementing a labor-market-oriented VET system involves developing a system of 
coordinated governance whereby both the central government and decentralized stakeholders have a voice (as explained earlier in this section). In some MENA countries, such as Tunisia, the vocational post-secondary training system is controlled by centralized government agencies that manage the system without the involvement of social partners. In other MENA countries, such as Egypt, Jordan and Lebanon, the coordination of a common strategy proves difficult despite the involvement of private sector and social partners (Carrero 2006). Consequently, the linkage between skills provided by the VET system and those demanded by the private sector is weak. In cooperation with the European Union, an extensive "TVET Reform Program” is being implemented in Egypt between 2005 and 2013. This reform program has a core focus on strengthening the labor market link by establishing local and sectoral Enterprise Training Partnerships (ETP). According to the project's website (www.tvet.org), 12 sectoral ETP could be established so far, predominantly in the areas of manufacturing, construction and tourism.

Further challenges to be met in MENA countries include insufficient funding and a missing incentive-system on the part of the training institutions, both of which are likely crucial determinants of training quality. While the funding of VET centers predominantly occurs via public budget allocations (based on past enrollment), student fees are usually limited and only cover administrative costs (Egypt, Tunisia, Jordan). The MANFORME reform in Tunisia initiated during the 1990s aimed at increasing the accountability of training centers through output-based funding, yet was hampered by the high degree of centralization, thus limiting the scope for the autonomous action of training providers. In further decentralization reforms, the training centers were provided with greater autonomy and a self-management structure within a standardized framework, however performance-based funding is still missing (Masson, Baati and Seyfried 2010). A performance-based rewards system requires a continuous monitoring and evaluation of training institutions, which is difficult to implement. A project initiated by the European Training Foundation on the exchange of knowledge about the quality monitoring of VET in Mediterranean countries (including Algeria, Egypt, Israel, Morocco, Syria, Tunisia and Turkey) noted weaknesses with respect to the evaluation practice. Monitoring and evaluation predominantly focused on input indicators (teachers, facilities, curricula) rather than the success of the VET in achieving training objectives. Furthermore, when performance-based indicators were used, they did not seem to be adequately applied to re-assess and improve the current system (Masson, Baati and Seyfried 2010). 
Besides the concerns of governance and funding, a further challenge concerning the extensive implementation of the vocational system is its stigmatization as a second-choice education (Bardak 2006). With the financial inability to provide an academic education system for all, governments use an early tracking of students into the vocational system to limit demand for higher education. Also evident by its insufficient link to the labor market, the VET system tends to be marginalized as a low-status track for poor academic achievers (Vlaardingerbroek and El-Masri 2008; Oketch 2007). Early figures on the return to vocational education show that they are associated with a lower return than secondary education (Heynemann 1997). The quantitative role of the school-based VET is therefore rather limited, with general, nontechnical secondary education representing the standard education in the majority of MENA countries.

Russia and other Transition Economies. Since the start of the transition, general trends have involved the move of vocational education from firms to schools, thus weakening the links between schools and enterprises; and the declining enrollment in vocational and technical schooling, often counterbalanced by the expansion of general secondary schools and tertiary education (Saar, Unt and Kogan 2008). As noted by Micklewright (1999), this was due to a mix of demand and supply factors, including the closure of enterprise-based schools and the shift of students towards general secondary schools with the purpose of obtaining broader education, more appropriate in a market economy, particularly at the time of structural changes. Having previously produced more than 50 percent of all secondary graduates in most countries, the vocational school system collapsed very quickly. Students left vocational schools in favor of general secondary education and the prospect of pursuing a tertiary degree. However, employers now assert that it is increasingly harder to find graduates with technical skills (Sondergaard and Murthi 2012).

Despite the overall trend in the transition countries representing a shift towards a schoolbased system characterized by a clear distinction between education and work, important elements of the dual system remain in the region, especially in Central Europe. They are presently visible in the Czech Republic, Hungary, Romania and Slovenia, and also Serbia. Moreover, some elements are also present in Poland and Slovakia, as well as Croatia (Matkovic 2008).

Evidence suggests that the transition system of VET has been far from desirable, with several studies identifying the following inadequacies that could be improved with the current VET system (Bejaković 2004; World Bank 2005; Bartlett 2009): (1) subject-specific specialization 
takes place too early; (2) the curriculum is too narrowly focused on subject-specific skills and competencies; (3) the provision of VET is excessively decentralized across different Ministries, leading to the multiplicity of structures; (4) training systems are inflexible and unable to adapt to the new labor market needs; and (5) institutional links between schools, employers and social agents are lacking.

Sub-Saharan Africa and South Africa. Most Sub-Saharan countries have formal, institutionalized technical and vocational education and training at lower- and upper-secondary or post-secondary level, mostly taking place in parallel to general education in integrated schools. However, in many cases the distinction and relative shares of general and vocational education at different levels of secondary education are not transparent. Moreover, these programs do not relate with the dominant economic activities within the informal sector.

Differences exist by region and country, with available data, despite being somewhat incomplete and dated, indicating that enrollment in vocational education as a share of those enrolled in secondary education was below 10 percent in most countries in the early 2000s, apart from very few cases such as Liberia, Mali (with both reaching more than 30 percent), Angola, Rwanda and Sierra Leone (with more than 10 percent)--DFID (2007) and Atchoarena and Delluc (2001). To some extent, differences in the level of VET enrollment can be explained by long-standing differences between French-speaking and English-speaking countries, with the former placing greater emphasis on general content and achieving higher enrollment rates than the latter. However, French-speaking countries neglect more artisan skills, leaving the needs of a mostly informal labor market unmet, as is the case in Cote d'Ivoire, Madagascar, Mali or Senegal (Atchoarena and Delluc 2001; Oketch 2007). In contrast, English-speaking countries generally have a more narrow vocational specialization and less academic content, further limiting educational progression unless these systems are modernized and rendered more flexible (as was the case in Ghana, Botswana and South Africa, to some extent). Furthermore, data shows some decline in vocational education enrollment in many countries over time - with girls hardly enrolled at all. In most countries, the provision of vocational education is a government responsibility via schools and training centers, despite private training providers having grown in importance.

Overall, formal vocational education and training have a difficult standing in Sub-Saharan African countries, despite some evidence that VET leads to better integration into wage employment, as shown by two studies on Ethiopia (Garcia and Fares 2008; Guarcello, Lyon and Rosati 2008). The difficulties with the promotion of technical and vocational education and 
training can be attributed to a number of issues, as summarized below (Oketch 2007, and Atchoarena and Delluc 2001):

1. In many Sub-Saharan countries, VET only meets limited acceptance by young people and their families as the benefits expected from VET (relative to general education) in terms of access to jobs, better pay or job promotion are far from obvious. Moreover, existing VET programs are often perceived as an unattractive option leading to dead-end jobs. Therefore, it is only seen as an inferior alternative to general secondary schooling (Garcia and Fares 2008).

2. The high shares of informality in economic activities and employment lower the potential for productivity increases, technological innovation and formal job creation. Stronger employer demand for better skilled workers in more productive activities would generate stronger incentives for participation in formal VET; however, given existing firms and jobs, traditional apprenticeships after primary education seem sufficient to gain access to employment.

3. There is generally only limited institutional support on behalf of policy makers, governments and ministerial agencies, who would have to greater engage with VET at schools (and in cooperation with business). Moreover, expanding general education tends to crowd out vocational education.

\section{Evaluating School-Based VET versus General Education}

Empirically, analyzing the returns to vocational education relative to those of general school education is a difficult task, for at least two reasons. First, given that the VET track is often intended for youths with lower motivation and ability, non-causal estimates of the returns to vocational education will be downward biased (Willis and Rosen 1979; Tuma 1994; McCormick, Tuma and Houser 1995). Second, as different occupations may require a different mix of academic or practical skills, youths with different skills are found in different occupations that are often not comparable due to differences including employment patterns, payment structures and union coverage.

Evidence from the US seems to indicate that, once selection into VET has been accounted for, its participants perform equally or better in terms of employment and wages than highschool graduates, and moreover these returns have increased over time. In contrast, evidence in the UK indicates that academic education leads to higher returns. Nonetheless, there is 
important heterogeneity regarding the type of VET obtained. More specifically, benefits from VET arise when there is a good match between the VET and the occupation of employment. However, causal interpretation of the results remains questionable, with many factors remaining unobserved in the selection process, including norms of peers and the neighborhood, and teachers' ability (Schlotter et al. 2011). Recent causal estimates for Sweden, the Netherlands, and Germany do not find any effects on wages or the employment probabilities of students participating in VET relative to general education. Although reliable evidence on the relative effectiveness of general versus vocational schooling from developing countries is scarce, two important results seem to emerge. First, the effectiveness of vocational skills appears to depend on the local demand for labor in the private sector and the ability of individuals to find employment in the occupation of training. Second, studies addressing the selection into VET problem seem to find that VET is beneficial for both men and women in the developing world. We summarize the key findings below.

Evidence from Developed Countries. Unable to exploit exogenous changes in the institutional setting, the majority of the studies conduct descriptive analyses controlling for students' characteristics such as grades and test scores achieved prior to accessing VET or remaining in general education, family background and local economic conditions, to capture the expected opportunity of longer schooling duration. Additional confounders include subjective statements of the preferences for VET of academic studies (Bishop and Mane 2003), subjective self-assessments of ability (Hotchkiss 1993), and information on the vocational orientation of the school captured by full-time vocational teachers and the schooling choice of previous cohorts (Meer 2007).

Returns to attending technical schooling in the US seem to have increased over time. For example, Hotchkiss (1993) investigates the short-run effects of vocational schooling on employment and wages of high-school graduates in 1980, finding no returns to vocational schooling even after controlling for training-related occupation choice. In contrast, Bishop and Mane (2003) and Meer (2007) investigate the short- to medium-run effects of participating in technical schooling among high-school graduates in the US during a longer time period. While the former find youths to greatly benefit from choosing the vocational schooling track both in terms of employment and wages, Meer (2007) finds positive but small wage increases, explaining these differences by using a more elaborate selection equation. Mane (1999) assesses differences in returns to technical schooling for high-school graduates between the 1970s and 1990s more systematically, confirming this positive trend during the 1980s and 1990s. 
In the UK, earlier studies comparing the returns to vocational and academic schooling frequently found a markedly lower return to vocational education, explained by academic jobs providing access to better paid occupations (Robinson 1997). Providing evidence that lower ability and family background are also important drivers behind lower levels of education in the UK, Dearden (1999) casts doubt on the causality of these findings. Reassessing the earlier findings, Dearden, McIntosh, Myck and Vignoles (2002) largely confirm the finding that academic education leads to higher returns, yet find significant heterogeneity regarding the type of VET obtained. In particular, it is found that the majority of vocational education programs increase earnings relative to no vocational qualification, especially for low achieving school leavers. One exception is the NVQ2, a VET course often undertaken during employment, which seems to have a negative impact on the wages of individuals, even relative to those with no other qualification (Dearden, McGranahan and Sianesi 2004).

Some studies from the UK suggest that the pay-off from vocational education is highest when individuals manage to find employment in a training-related occupation. For example, they show that the vocational qualifications of being a nurse or a teacher, where they are needed most, have their highest returns in public employment. Similarly, and in a different economic context, Neuman and Ziderman (1999) investigate the differences in returns to vocational versus academic schooling in Israel, also highlighting that the large part of VET benefit only arises when a good match can be established between VET and the occupation of employment.

Three studies from Sweden, the Netherlands and Germany have been able to exploit exogenous policy changes increasing the duration of general schooling in the vocational schooling tracks of those respective countries. In contrast with earlier findings, none of the studies finds an effect on wages or employment probabilities of students. Oosterbeck and Webbink (2007) investigate the increase of duration of the vocational schooling track in 1975 by one year in the Netherlands, with the additional year designated only to general schooling. Adopting a difference-in-difference strategy, they investigate the effect of the change on wages 20 years later, and do not find any effect. Pischke and von Wachter (2008) exploit the gradual adoption of a one year increase in compulsory schooling in the lowest schooling track in Germany between the 1950 to the 1970s, investigating the changes on long-term wages, yet do not find any effect. While the previous studies consider extensions of general schooling at the lower secondary vocational tracks, Hall (2012) assesses a policy change in Sweden in 1991 that increased the general education content of the vocational schooling at 
the upper secondary level, increasing its duration by one year. Upon completion of this new vocational track, students were eligible to enroll in tertiary education. Exploiting random differences in time and the regional implementation of a policy pilot, Hall (2012) does not find any effects on subsequent study take up, nor any increase in the wages earned up to 16 years after the beginning of upper secondary school. However, as a negative consequence, low achieving students are significantly more likely to drop out of upper secondary education.

Part of the discussion between "generalists" and "vocationalists" concerns the performance of skills in dynamic economies, where skills have to be adapted to technological change and be mobile across firms, occupations and space. With only a minor vocational track, the US education system is an obvious representative of the generalist scheme. Goldin (2001) argues that the general schooling focus in the US represents a crucial factor in determining the countries' economic performance in the $20^{\text {th }}$ century. While general schooling might be more costly to invest in, general skills are more flexible and transferable, and are hence valued higher when there is a high probability of technological change. If this were true, the returns of vocational education would be expected to decrease over the lifecycle of individuals.

Hanushek, Woessmann and Zhang (2011) are the first to analyze employment differences of general and vocational schooling over the course of individuals' working life in European countries, with their descriptive evidence highlighting a faster initial integration into the labor market of vocational education participants. At the same time, their statistics for the vocational track show decreasing labor market participation towards the end of their working life, which seems suggestive of the hypothesis that occupation-specific knowledge outdates faster and hence leads to lower employment opportunities later in life. However, more reliable evidence on the perceived trade-off is required, as the causal interpretation of these findings is impeded by occupation-specific segregation of the labor market and the limited availability of long-term panel data.

Evidence from Developing Countries. Reliable evidence on the relative effectiveness of general versus vocational schooling from developing countries is scarce. Earlier evidence, dominated by the overview studies of Psacharopoulos (1973, 1985, 1987, and 1994) and Psacharopoulos and Loxley (1985), generally reached the conclusion that the high costs associated with vocational schooling did not relate to its benefits, with the latter measured in terms of economic returns to these skills. However, later reexaminations of these findings suggest that the majority of studies used in these syntheses do not adhere to common evaluation standards, through the lack of sufficiently informative data and an insufficient 
consideration of heterogeneity across countries (Bennell1996). Furthermore, the focus on economic returns to vocational education might be deceptive, in light of the structurally low labor demand in the private sector of some of these labor markets. Holsinger and Cowell (2000) discuss the study by Psacharopoulos and Loxley (1985) for Columbia and Tanzania, highlighting that participation in lower vocational schooling lowered the drop-out rate and increased the educational achievement of students. A more recent review by Chung (1995) provides mixed findings on the effects of vocational education, finding both positive and negative outcomes. The effectiveness of vocational skills generally seems to depend on the local demand for labor in the private sector and the ability of individuals to find employment in the occupation of training (Bennell andSegerstrom1998; and Middleton et al. 1993).

More recent evidence from developing or transition countries on the relative effectiveness of vocational schooling versus academic schooling remains mixed, pointing to the determinants of country specific heterogeneity (see Almeida, Behrman and Robalino, 2012 for a thorough literature review in developing countries). Kahyarara and Teal (2008) investigate the returns vocational education tracks in Tanzania, finding the continuously strong preference for academic education to be driven by the extremely high returns to high levels of academic education. Furthermore, they show that lower levels of academic education and vocational education have very similar returns, suggesting that the convex return to education is at least partially driven by the selection of these individuals into large, higher paying firms. Moenjak and Worswick (2003) compare the returns to the two vocational and academic tracks at the upper secondary level in high schools in Thailand, where both tracks qualify individuals to enter higher tertiary education. When controlling for positive self-selection using a Heckman selection correction, their results point to a higher return to vocational education. Newhouse and Suryadarma (2011) analyze the returns to vocational versus academic high-school tracks in Indonesia, with their results on labor market returns suggesting a change in the returns to vocational education over time, with significantly higher wage returns for older cohorts yet lower returns for younger cohorts. They explain this by the decreasing value of vocational skills in the increasingly service-oriented Indonesian economy. Tansel $(1994,1999)$ and Tunali (2003) provide evidence for the returns to vocational high-school education in Turkey, suggesting that the vocational tracks perform superior to the academic tracks in terms of wages for men and employment probabilities for women. Women seem to benefit from vocational schooling tracks by experiencing a higher probability of participating in the labor market. 
In summary, the evidence suggests that the private returns to vocational schooling are very similar on average, and in many cases higher than those of general schooling. Changes in the relative returns of the two education options over time emphasize the continuous need to adapt the vocational system to changes in labor demand, which can hence be declared as one of the main challenges associated with the implementation of the vocational schooling system. While differences across countries might be driven by differences in the implementation, the return to vocational schooling also depends on the labor market institutions in a respective country, and the willingness of employers to invest in skills onthe-job. Almeida, Behrman and Robalino (2012) present evidence suggesting that employers have different expectations regarding the generality of skills that youth should have when entering the firm. The reasons for these differences might lie in the institutional settings (such as the flexibility of labor market regulations) and historical and cultural differences with respect to the organization of work processes.

\section{Dual Apprenticeship System}

Dual VET aims to combine general, transferable skills acquired during class-based VET with structured learning on the job and actual work experience within a training company. Apprenticeship graduates acquire occupation-specific skills that render them employable by the training company or other employers. Overspecialization and low levels of transferable skills generated by the higher share of firm- and occupation-specific training is counteracted by standardized curricula and examinations.

The overall fascination with a vocational education system where the firm imparts both certified general and firm-specific education is grounded in the notion that firm-based training might solve several problems associated with purely school-based training systems (Heckman 1993). In a world of perpetual technological change, a dual VET system is expected to be less prone to problems of educational mismatch early in the career, with firms expected to timely adapt their training curricula to changes in the skills demanded. While the adaptation of school-based education crucially depends on continuous and accurate labor market feedback, firm-based training is expected to lead to a natural leveling of labor supply and demand. In addition, with the immediate putting-into-action of acquired skills and the exposure to an adult working life, the dual system might provide a more beneficial learning and working environment for practically oriented youths, increasing their motivation and engagement in training. Finally, by establishing an early contact to firms and work- 
experience, youths enter faster into the labor market - by either remaining in the same firm or gaining easier access to further employment - and learn about the types of jobs and occupations that they may prefer.

While dual training exhibits several advantages from a societal and individual perspective, establishing an efficient dual apprenticeship system depends crucially on the willingness of firms to participate. To ensure transferability of skills across firms after the apprenticeship, a sufficient amount of general schooling should be provided during the training. However, as noted by Becker (1964), while some share of general schooling is crucial in enabling apprentices to enter further employment relationships, in a perfectly competitive labor market where workers are paid according to their marginal productivity, firms have no incentives to invest into general schooling as workers can leave directly after the training period and reap all the benefits of their acquired general skills. Hence, in order for firms to provide both specific and general training, the cost of general training is to be borne by the worker. This could be implemented by either providing state-funded school-based general education or firm-based general training, with workers paying for their training costs. Furthermore, firms could be incentivized to participate if they were able to recoup part of their investments by contractual arrangements ensuring that apprentices accept a wage lower than their marginal productivity during their training period, or if they are able to tie apprentices to the firm beyond the training period (Becker 1964; Malcolmson et al. 2003).

\section{Why Would Firms Invest in General Training?}

Based on the empirical finding that firms in some countries (such as Germany) invest in general training despite incurring a net cost during the training period (Dionisius et al. 2009), several theories attempt to explain the training activities of firms (see Wolter and Ryan 2011 for an excellent overview). In particular, Acemoglu and Pischke (1998, 1999, and 2000) develop and extend the framework of Katz and Ziderman (1990), where informational asymmetries regarding the abilities of workers and the quality of training received can lead to sufficient incentives for firms to invest in general training. Given that firms are able to learn the ability of the worker during the training period, the additional presence of a compressed market wage allows firms to pay high ability workers less than their marginal product, hence reaping part of the benefit of training. A compressed wage structure might arise due to: (i) information asymmetries and complementarity between ability and training in the production function (Acemoglu and Pischke 1998); or (ii) search costs combined with market frictions 
such as firing costs, which are higher for high-skilled workers, collective bargaining and minimum wages (Dustmann and Schönberg 2009). While these components are necessary to ensure incentive compatibility on the part of the firm, Acemoglu and Pischke (2000) highlight the existence of external certification as a signal to prospective employers that the trainee is willing to invest in their own training. Dustmann and Schönberg (2012) further extend this framework by suggesting that the dual apprenticeship system is likely more successful in countries where firms can credibly commit to the provision of training during the apprenticeship, through apprenticeship regulation and external accreditation.

Another set of models aims to explore the deterring effect of poaching, which implies that firms that do not invest in training might hire apprentices from the training firm by offering them slightly higher wages. Accordingly, several models investigate this hypothesis by exploring exogenous differences in the competition for dual training leavers. Indeed, if firms are able to enjoy some monopsony power arising from industry- and occupations-specific skill requirements, dispersed regional location of firms and lower product market competition, it can be found that they are more likely to engage in training (Lazear 2003; Smits 2007; Gersbach and Schmutzler 2006).

A further potential reason to participate in training might be that firms like to ensure their own future skill supply through the provision of training. However, some countries, such as Switzerland, maintain a large dual system and a high turnover rate after training (Wolter and Schweri 2002). It might be the case that firms train apprentices to use them in current production. Although firms might incur a net cost for the average productive apprentice, some high-productivity apprentices might also be paid less than their marginal productivity, given that the overall wage level for apprentices tends to be low (Mohrenweiser and Zwick 2009). In particular, if the outside options for youths are low, they might be willing to engage in such a payment scheme as they can later benefit from their skills acquired. High training regulation and external certification could be implemented to prevent youths being exploited as cheap laborers during the training phase.

\section{Implementation Strengths and Challenges}

Dual VET is common in Austria, Denmark, Germany and Switzerland, and partly in the Netherlands and France. The dual apprenticeship system in the German-speaking countries (Austria, Germany, Switzerland) is generally considered as the archetype of the dual approach, accommodating from 40 percent (Austria) to 80 percent (Switzerland) of all school leavers. The 
three countries share some common and distinctive features in the set-up of the dual vocational education, which we outline using the example of Germany, with the four key institutional elements of the dual system described below:

1. A high degree of formalization that only provides training in centrally accredited occupational qualifications. The training content is continuously adapted to meet the changing requirements of the labor market.

2. Strong involvement of social partners in developing and maintaining curricula at the governmental and federal level, through representative advisory boards. The implementation and monitoring is undertaken by regional trade and/or occupational committees.

3. The school-based part of the dual apprenticeships is provided by vocational colleges, covering both general and occupation-specific education. The costs of training in the schools are borne by the government.

4. Firms have to meet certain technical standards to be accredited as a training firm. Offering apprenticeships is optional for companies, with the match between firms and trainees following standard application procedures. The costs of training within the firm are covered by the training companies.

Germany. Occupation-specific training regulations that define the duration, content and syllabus of training lie at the heart of the dual apprenticeship system in Germany. Issued by the federal government, the regulations currently cover 350 officially recognized occupational degrees, defined with the advice of employers and trade unions. Based on these regulations, the training firms and trainees sign a temporary contract for the duration of the apprenticeship. A committee of the local Chamber of Crafts or Commerce monitors whether working and training standards in the firms are met, also conducting the final examinations required for certification. The regulatory exclusivity of the training and certification process aims to ensure the transparency and transferability of the skills acquired, with continual efforts made to adapt the training standards to changing labor market needs. The Federal Institute for Vocational Education and Training undertakes continuous research towards this purpose, providing a platform for dialogue between the federal government, employer representatives and trade unions, such as reforming or introducing training occupations. The setup of the dual 
apprenticeship is generally standardized to a two to four year duration, during which the trainee participates in training within the firm and a vocational school, in an alternating matter. While the school-based training provides both general and occupation-specific knowledge, training within the firm contains firm-specific elements.

There is no obligation for firms to participate in training in Germany, with around 50 percent of all companies registered with the Chambers of Crafts or Commerce currently authorized to provide training within dual apprenticeships, although only half of them actively provide apprenticeship places (BMBF 2011). Given that training is costly for the firm, the share of training firms can be found to be higher amongst larger firms. Furthermore, firms tend to adapt their training activities to economic conditions and the projected demand for skills, which makes the number of apprenticeship offers sensitive to economic fluctuations.

If firms want to participate in the dual apprenticeship system, they have to be accredited by the local Chambers of Commerce and bear the costs of training facilities and training personnel. The teachers in the firm are required to have substantial experience in the relevant occupation as a foreman or master craftsman, whereas teachers at the school-based part of the apprenticeship hold academic qualifications. Continuous in-service-training is compulsory for both types of teachers (Hoeckel and Schwartz 2010). During the training period, firms further have to provide some basic level of remuneration, which is continuously adapted and subject to the collective bargaining in some industries. The costs of training at vocational schools are borne by the government. The retention rates of youths in the firm following the apprenticeship depend on the current economic environment. Between 2000 and 2009, the conversion rate of apprenticeship contracts into regular employment varied between 50 percent and 60 percent (BMBF 2011).

Austria, Denmark and Switzerland. Within Continental Europe, Austria, Denmark, and Switzerland are most similar to Germany in also relying on a strong dual apprenticeship system as part of their upper secondary vocational education. However, variations in the institutional details arise across the respective countries due to institutional, political and economic differences.

Differences between the Danish and German system arise in terms of a more decentralized planning of the educational content in the vocational schools in Denmark (Cort 2008). While the German system issues training plans in the school-based part at the state level, the local entity in Denmark is much smaller and represented by 115 vocational colleges. Furthermore, 
these colleges enjoy a higher level of autonomy in terms of designing curricula, as the Ministry only issues directives rather than concrete plans. In contrast, the Austrian and Swiss systems are entirely centralized, with school and firm curricula developed at the state level. This leads to a higher degree of standardization of the occupational degrees, potentially enhancing the mobility of workers across firms and regions (Ebner 2009).

All countries face the problem of cyclical variations in the supply of apprenticeship places due to the voluntary participation of the firms in dual apprenticeship systems, which might leave youths entering unemployment before integrating in VET. Hence, incentive mechanisms have been implemented for firms to stimulate supply. For instance, Austria offers financial incentives for firms to become a training company or increase their training activities (Ibw 2009). In Denmark, an “employers’ reimbursement fund” was established already in 1977, with all companies having to contribute as a function of their company size, yet independent of whether they participate in the system. When they participate, 90 percent of the wages paid to trainees during the school-based training periods are financed by this fund (Cort 2008).

Furthermore, all countries share the problem of disadvantaged youths being unable to obtain a training contract with a firm or persevere and successfully complete the apprenticeship. A support system was put into place for these "practically oriented youths", and is most developed in Denmark. Here, several modified versions of the apprenticeship and specialized vocational education programs aim to increase the chances of youths with learning disabilities or other disadvantages to successfully complete upper secondary education. Basic vocational education and training constitutes an individualized VET program specifically designed for the particular requirements of individual youths below 30 who are unable to participate in ordinary VET. Moreover, production schools absorb youths below 25 who have experienced difficulties entering or remaining in the other training options, providing a practical work experience in manufacturing-type jobs along with vocational guidance. Furthermore, partial qualification programs offer a certified degree after a shorter training duration (Cort, 2008). In Switzerland, specific occupational training programs were initiated for youths with insufficient performance in compulsory education and difficulties entering the regular dual apprenticeship system. Within these programs, youths are trained in standardized partial occupations for an average duration of two years, and upon completion receive an occupational certificate that can be used to enter the labor market or start full occupational training (Kammermann et al. 2011).

Russia and other Transition Economies. Under socialism, many Central and Eastern European 
countries operated an extensive dual apprenticeship system with alternating school- and firmbased training. However, following the transition to the market economy, dual system training came under pressure and employer-provided training places plummeted (Ost 2000). Moreover, governments were unable or unwilling to create sufficient financial incentives for training provision. In some countries such as Hungary, the growth of school-based training places more than compensated for the decline in employer-provided training. However, the lack of on-thejob training or the coordination of employers and training providers led to an increase in skill obsolescence and mismatch, with school-based training frequently decoupled from current labor demand (Noelke and Horn 2011). Another adverse consequence was the increasing difficultly for young vocational school graduates to enter the labor market. Consequently, there was an increase in the relative demand of general secondary education granting access to tertiary education, which led to creaming the most socially advantaged students towards the academic track, thus exacerbating social inequalities (Bukodi and Péter 2011).

Latin America. VET in Latin America started with the economic expansion that followed World War II, when the demand of the manufacturing sector exceeded its ability to provide on-the-job training. The peculiarity of this region is the evolution of such programs over time, whereas two different phases can be recognized (Betcherman et al. 2007; Puerto 2007). This first phase of the development of VET can be dated to the foundation of the National Service for Industrial Training in Brazil (SENAI) in 1942, and the following National VET Institutions (VTIs) that emerged in the whole region on the same grounds. The SENAI was originally strongly influenced by the German dual system, with each occupation was broken down into its constituent tasks, which were added into the training curriculum and applied in practice projects. However, the dual system could not be recreated due to the lack of master craftsmen (Cinterfor 2008). Subsequently, the VTIs were primarily supply-driven, state managed, financed through payroll taxes, independent from academic schools and from the Ministry of Education, and usually quite closely reflected the industry's needs (de Moura Castro and Verdisco 1998). VTIs had a tripartite structure throughout the region, with representatives of employers, workers and the government and the curricula determined centrally. However, the VTIs did not adapt to the changing economic structure after the 1970s, and the economic challenges and subsequent downturns posed by the oil crisis. At this point, the demand for skilled and semi-skilled labor from the manufacturing sector started to decline, with graduates from these programs unable to find employment, informal labor markets became more common, and budgets were dramatically cut for all these 
institutions. Such a reduction in the emphasis on these programs also resulted from the preference for programs driven by market principles and dramatic changes in the demand for labor (de Moura Castro and Verdisco1998).

The second phase of VET programs targeted programs to certain segments of the population, particularly disadvantaged youths. The Jóvenes Programs were created in the early 1990s, and remain important training programs in the region. Such interventions are based on a demand-driven model targeted at disadvantaged youths, with the first program created in Chile and subsequently replicated in Argentina, Uruguay, Paraguay, Peru, Colombia, the Dominican Republic and Venezuela. These programs targeted youths from low-income families, the poorly educated and unemployed or underemployed. Unlike the VTIs, the Jóvenes programs were not run by the government, yet they did regulate them: training was offered through a bidding system where private and public firms could participate, and was therefore demand driven in the sense that the government did not set the contents of the curriculum. Similar to the dual VET system, a classroom-training phase was followed by an internship (Ibarrarán and Rosas Shady 2009). According to Weller (2009), the main changes and differences compared to the original VTIs are:

1. A greater diversity diversification of training providers, with stronger reliance on private institutions. In the public realm, delivery and regulation were institutionally separated and programs were decentralized, which implied greater participation by local entities (provinces and municipalities).

2. More articulate interest in the certification of skills, facilitated by a larger variety of training offered and the recognition of informal learning.

3. Attempts at making training more demand-oriented through the greater involvement of private enterprise and trade unions, which helped to identify unmet needs.

4. More diverse target groups, with a shift from one-time training to continuous training for personnel of strategic importance for the firm's competitiveness; however, on the other hand, training programs were designed to encourage the reintegration of the unemployed and special schemes for groups with particular employability problems (youths and women with low education levels) or those 
working in low-productivity, low-income activities (specific occupations, ownaccount workers, micro-entrepreneurs).

\section{New instruments for the public funding of training, particularly tax incentives.}

These programs seemed to have guaranteed the participants' increased employability and higher earnings upon graduation (Betcherman et al. 2007), with Table 1 describing some of these programs and evaluations in different countries. Overall, the Jóvenes model has been successful in improving the job placement and earnings of disadvantaged youths, particularly for disadvantaged females. This model is less close to the dual vocational system than the VTIs of the previous phase, yet has found to be successful. However, the original Jóvenes programs have now become particularly expensive for some countries, due to the long duration of the program reaching an average of eight years (Betcherman et al., 2007).

\section{Evaluating the Dual-versus the School-Based System}

It is generally found within cross-country comparisons that those maintaining a substantial dual apprenticeship system, such as Austria, Denmark, Germany and Switzerland, exhibit a much smoother transition from school to work, low NEET rates and youth unemployment, and below average repeated unemployment spells than other countries (Quintini and Manfredi 2009; Quintini, Martin and Martin 2007). However, it must be noted that labor market transitions of youths only provide partial evidence for the relative performance of the training systems in the respective countries, with a causal analysis clearly impeded by the co-variation of other relevant institutional factors. Further problems arise from the absence of a unified framework for defining the respective training options and collecting data on the costs and benefits experienced by the state, firms and trainees (Hoeckel 2008).

A more extensive area of research exploits the co-existence of apprenticeships and other types of vocational schooling within countries to generally infer about their relative effectiveness and more specifically the relevance of firm-specific skills. For the case of Germany, studies by Winkelmann (1996) and more recently Parey (2009) show that participation in the dual apprenticeship has the particular advantage compared with other options of the vocational schooling system of improving early labor market attachment and a faster and more structured integration into the labor market. However, this advantage fades over time as other education participants find a foothold in the labor market. Furthermore, 
the studies show that the fast initial transition does not hinge on finding employment in the training firm, suggesting that firm-specific skills do not play a major role in the German apprenticeship system. Investigating wage differentials, Parey (2009) does not find any significant differences in return to the training options in the early working life. A recent study by Adda et al. (2011) considers the relative employment and wage profiles of participants in the dual apprenticeship system and unskilled workers in Germany over 15 years following initial labor market entry. They find that having participated in formal, work-related training (the apprenticeship) leads to overall higher wages compared to pure onthe-job training (unskilled) and a stronger labor market attachment, thus compensating workers for initially low wages during the apprenticeship training.

Similar results on the performance of apprenticeship training versus school-based training are found in studies by Bonnal et al. (2002) for France and Plug and Groot (1998) for the Netherlands. Correcting for the negative selection of youths into the dual apprenticeship, both studies find that apprenticeships perform significantly better in integrating youths into their first employment relationship by the higher labor market relation of their training. However, again this advantage is found to fade over time and is not associated with higher wages. A recent study by Alet and Bonnal (2011) shows that young people integrated into the dual apprenticeship system rather than vocational schooling in France are more likely to successfully complete their final exam and undertake further education.

In countries where the dual apprenticeship is not seen as a "trainer of last resort" for lower skilled individuals, the apprenticeship system is also found to partially act as a mechanism to level the playing field for youths with low school performance. Exploiting information on PISA test scores to capture differences in ability across students, Bertschy et al. (2009) show that lower performing youths in Switzerland tend to select into less demanding apprenticeship occupations and are thereby penalized in the labor market - however, their initial test-score (as signal of their ability) is no longer important in determining labor market outcomes.

The bottom line is that, once selection is accounted for, the dual system seems to offer an advantage of improving early labor market transitions (measured in a variety of ways). Nonetheless, evidence seems to indicate that these benefits eventually fade away. Given that the dual system tends to be more effective than school-based VET, why is it not as broadly implemented around the world? The next section reviews countries' efforts to establish a dual-system around the world. 


\section{Establishing a Dual-System Around the World}

It is generally important to consider that the dual VET depends on some essential preconditions, for instance it relies on strong cooperation between government and employers regarding the development of the institutional framework for VET, the development and adjustment of curricula, the certification of competences and co-funding of plant-based and school-based elements. In addition to these regulatory and budgetary issues, the dual system also depends on active support from actors as described below:

- The acceptance of apprenticeship contracts paid below regular contracts by trade unions;

- The willingness of many employers to provide training, not primarily in an informal manner but according to occupational curricula, to send apprentices to vocational school leading to certified occupational qualification, and to provide them with a credible prospect of sustainable employment;

- The support from the government in not only providing vocational schools and teachers but also preparatory training for young people failing to enter apprenticeships;

- The acceptance of VET by young people and their parents as a solid alternative to academic education.

These elements tend to being mutually reinforcing. As they have developed over a long time, these conditions cannot easily be transplanted to a different institutional and historical context. However, many countries have tried to develop dual VET programs as described below.

In the US. Numerous efforts have been made to establish a dual apprenticeship system for the vocational education of youths in the US. For instance, the National Youth Apprenticeship Act under the administration of George Bush and the School-to-Work Opportunity Act under President Clinton were two attempts at implementing the dual system. However, according to Lerman and Rauner (2012), wide-spread participation in the youth apprenticeship could not be reached due to the inability of employer organizations to coordinate long-term training plans, and the federalist division of responsibilities that impeded a binding national framework for the training systems. Furthermore, there is a 
general mistrust in the idea of imparting specific human capital, as it is likely perceived to lose its value more quickly in a continuously changing labor market (Krueger and Kumar 2004). Consequently, tracking youths in high-school into occupation-specific and general education prompts some concerns regarding stigmatization and limited opportunities for the occupation bound youths. Finally, there appears to be a lack of interest in participating in this exchange on the part of employers. They are unwilling to endure the perceived high costs of training, not knowing whether they will be able to recover these costs at a later stage (Shapiro 1999). Despite the futile efforts at the federal level, some states were able to establish and maintain a functioning small-scale dual apprenticeship system, particularly in the construction industry (Bilginsoy 2003).

In Egypt. Based on the so-called 'Mubarak Kohl Initiative’ started in 1991, Germany has assisted Egypt in establishing technical and VET structures modeled along the lines of the German 'dual model', with its emphasis on dual training and societal consensus. It aimed at improving relations between actors such as ministries, vocational schools, training centers and firm-level training, as well as setting standards for occupational qualification. The German Society of International Cooperation (GIZ, Gesellschaft für Internationale Zusammenarbeit) supported the program until 2008 assisting in the development of training curricula and trained instructors. The provision of apprenticeships was coordinated by the newly created National Center for Human Resource Development related to private employers in Egypt as well as the Ministry-related Directorate for Vocational Education and Training. The program started to offer the possibility of entering into three-year courses of dual VET to secondary-school graduates in Egypt, in 28 occupations involving around 1,600 firms providing training and 44 vocational schools. Available qualitative evidence gained from interviews with participants and follow-up tracing points at a smoother transition of program participations from school to work and better earnings after completing dual VET. Employers continue to support the program, perceiving a better trained workforce as a major benefit (Adams 2010). The pilot is now established as a regular part of the Egyptian training system run by the Egypt Ministry of Education and the industrial partners, on a stable legal basis. As of 2009, 32 occupational profiles were trained in 76 technical schools involving around 1,900 companies, mostly in the formal and industrial sector. By 2009, 24,000 young people had graduated, with 13,000 in training. However, this is largely insufficient compared to the overall challenge in Egypt, which needs to integrate around 1 million young people into the labor market per year. Observers also question the sustainability of the program without external support. 
In Sub-Saharan Africa. There are some examples of modernized apprenticeship systems in Sub-Saharan Africa. For instance, Benin modernized its VET system in order to better meet urban economic demands, with a dual apprenticeship system with alternating phases of theoretical and practical training in place since 2006, mostly devoted to traditional crafts such as masonry, electrical trades and plumbing. While one day is spent at school, five days are devoted to learning on-the-job. Participants can obtain a certificate of qualification (certificat de qualification professionelle) after 600 hours in a training center. It is expected to have around 3,000 graduates per year, which indicates the small scale of the system. The new system should also be able to certify qualification from work experience. In Mali, where the VET share is far above the African average, a dual training model combining around 80 percent time spent on work supervised by a trained artisan and 20 percent formal courses in training centers was introduced in 1997. There is some evidence of this reform leading to better skill formation and inclusion into the labor market, particularly due to the systematic involvement of the private sector (Rioust de Largentaye 2009). Nonetheless, these models are relatively small and tied to traditional crafts. In Ethiopia, the education system was reformed in around 2000 to strengthen primary education for all young people, which now lasts for 8 years, and to complement this with vocational courses in technical subjects lasting for one or two years. There is some preliminary evidence of improved labor market performance of recent training graduates (Denu, Tekeste and van der Deijl 2005). As shown by the Gambian example of the National Youth Service Scheme established in the mid-1990s, young people mostly turn to self-employment or work unrelated to the occupations learned (Lahire, Johanson and Wilkox 2011). Still, a major challenge involves moving beyond pilot projects and establishing VET at a sufficient scale given the number of cohorts entering the labor market every year.

Despite multiple efforts to establish a dual-system of VET in quite diverse countries, successful initiatives remain relatively small-scale and tied to certain sectors such as the construction sector in the US or traditional crafts in sub-Saharan Africa. The challenges of establishing a mainstream dual VET system around the world highlight the need for a specific type of institutional framework, the complexity of which is not easy replicated in either developed or developing countries. 


\section{Informal-Based VET}

Owing to the persistently large share of informal employment in many developing countries, an important question concerns the role of informal vocational learning. In India and many African countries, the predominant source of vocational education or training is conveyed in a so-called traditional or informal apprenticeship system, outside of formal vocational or general schooling. While knowledge is transmitted between generations within a family or clan in "traditional apprenticeships", “informal apprenticeships” are open to apprentices not belonging to a family or clan (ILO 2011, 2012). Despite taking place in the informal sector, these traditional or informal apprenticeships have some locally standardized structures and duration, and are based on some contractual agreements between the craftsman and trainee. Apprentices receive no or little remuneration during the training period, and might even have to pay a fee to the trainer. The training is generally entirely work-based, but it may follow an informal training plan (ILO 2012).

Informal and traditional apprenticeships within the informal sector remain a major form of employment and training in many low- and medium-income countries. They are common in Sub-Saharan countries, the South Africa, Middle East and North Africa (MENA) region where vocational schooling programs are usually outdated, detached from the economy and perceived as inefficient and unattractive, as explained earlier. However, traditional and informal apprenticeships tend to be confined to crafts where technological innovation and company growth are limited. The transferability of skills acquired in traditional and informal apprenticeships is limited due to the lack of certification of training and work experience, and the absence of vocational schooling parts emphasizing general skills. Moreover, if some certificate is issued by the informal training employer, the acceptance of such a certificate is often restricted to a local community. Given the lack of a legal framework to enforce certain training standards, the informality of training may also bear certain risks to the trainee, with particular concerns involving the potential exploitation of children as cheap laborers, gender discrimination based on traditional gender roles, and unenforceable contractual agreements resulting in low training quality or an extension of the apprenticeship duration (ILO 2012).

\section{Implementation Strengths and Challenges}

The tradition of informal apprenticeship is particularly wide-spread in West African 
countries, with several common structural features emerging across the respective countries (Ahadzie 2009). It is generally found that training is purely practically oriented, with apprentices learning from observing the craftsmen at work in their trades and skills such as tailors, mechanics, painters, bakers, carpenters, joiners, welders and hair dressers. Consequently, the learning process might be restricted only to the production of specific type of output, leaving apprentices with only partial knowledge of their respective trade after finishing the apprenticeship. The duration of the apprenticeship is found to vary by type of trade and also the ability of the apprentice. Whereas the cost of the apprenticeship seems to be borne by the apprentice with the payment of fees or in kind payments, apprentices can also receive shelter and food during training, the value of which might exceed the total fees paid. The predominant source of apprentice recruitment is the familial and social network, with training potentially seen as part of a social reciprocity system. Whereas the general schooling levels of youths traditionally do not matter for the selection of apprentices, it is found that craftsmen seem to value a completed lower general education. Written contracts for the apprenticeship are not very common, and generally do not contain specifics of the content and duration of training.

In contrast to formal vocational education, informal apprenticeships bear the advantage of being closer to the current needs of employers in the (informal) labor market, which represents a large share of the economy in many countries. However, this type of training has its limits concerning modern and technology-oriented occupations, which in turn also implies the need to have employers and labor demand in these fields. Informal apprenticeships face major barriers regarding technological advancement, while informal employers are naturally restricted in their access to the credit required for investment and firm growth.

Sub-Saharan Africa and South Africa. There are traditional apprenticeships in workshops owned by master craftsmen, mostly in traditional occupations. Given the cost of school attendance and weak family background in some countries, enrollment in secondary education is far from complete, will some young people subsequently entering the (informal) labor market after primary education without any further formalized general or VET at the secondary level, rather taking up an apprenticeship in a small business or formalized village polytechnics.

Major parts of VET for informal activities are provided by non-government providers such as NGOs, churches, for profit agencies and, most importantly, informal entrepreneurs (Rioust de Largentaye 2009). Informal apprenticeships reach approximately 50 percent to 90 percent of 
young people in countries such as Gambia, Ghana, Senegal, Madagascar, Zambia, Tanzania, Mali and Malawi.

Continuous attempts are made to upgrade the informal training system through formalization. However, this is a difficult task given that the flexible forces of the traditional apprenticeship might easily be distorted and lead to "another supply-driven, dependency-induced training program” (World Bank 2004). Palmer (2009) discusses several attempts of the Ghanaian government to formalize informal apprenticeships, and highlights potential its unintended ramifications. In particular, he criticizes the global or partial take-over of training costs, as proposed by experts in the 2008 National Apprenticeship Program (NAP), as this falls short of the complex system of pecuniary and non-pecuniary payments made between apprentices, their families and the craftsmen during the training period. Based on previous experiences, partial payments could be particular distorting, as this might force poor apprentices to prematurely leave the apprenticeship. As the training plan is not structured, it is furthermore not guaranteed that youths are able to acquire sufficient skills during this period. Additionally, he notes that the substitution of the practical work-based training for a more general school-based schooling is likely to disregard the abilities of youths and skill demands of the local economy. He highlights the introduction of practical short-term training courses lead by public or private institutions to complement the work-based training as undertaken in the Vocational Skills and Informal Sector Support Project in Ghana as potentially promising measures, as well as the targeted training of craftsmen to ensure a minimal level of training quality. With respect to the latter, projects conducted in Ghana, Tanzania or Kenya seemed to work similarly well, significantly improving both the training content and quality of the output produced (ILO 2012).

A further hurdle to formalization and standardization is the missing or weak involvement of informal business associations. Despite factually existing in many countries, they are often not very strong representatives of their members due to a high degree of heterogeneity limited funding or lack of structure. Therefore, an ILO initiative in Niger targeted the restructuring of the National Crafts Association and an increase in their visibility in local communities. This led to a significant extension of their coverage, and thus a higher representativeness in political consultations regarding the formalization of traditional apprenticeships. Involving business associations is also found to improve training quality by increased monitoring, the definition of skill standards, or the joint acquisition of expensive tools (ILO 2012). 


\section{Effectiveness of Informal Training}

Compared to informal jobs without training, the informal types of VET is considered to improve the chance of achieving promotion inside informal businesses from unskilled to skilled worker, consequently earning a higher wage. Training is essential to become a master craftsman and set up or take over a business in these fields after some years of activity (Aggarwal, Hofmann and Phiri 2010; Nübler, Hofmann and Greiner 2009). Furthermore, compared to vocational schooling, which often relies on outdated curricula and lacks the involvement of employers in many developing countries, informal and traditional apprenticeships are coupled with current skill demands and work practices in the informal sector, with informal apprenticeship graduates more easily employed than graduates from vocational schools. Given that they do not require any formalized entry criteria, informal training often represents the only opportunity for schoolleavers to obtain vocational education (Walther 2011).

In terms of labor market outcomes, there is evidence from studies on Malawi and Tanzania that most graduates from informal apprenticeships were employed with the same business that had provided training, or with some other employer, and that after some years a considerable share of them were also self-employed (Aggarwal, Hofmann and Phiri 2010; Nübler, Hofmann and Greiner 2009). An evaluation study of the informal apprenticeship system in Ghana (Monk, Sandefur and Teal, 2008) shows an important negative selection of youths into informal apprenticeships, with youths with low levels of general schooling entering this type of training. However, when controlling for this negative selection, it is found that individuals with low levels of formal schooling benefit substantially from the informal training, with earning increases of 50 percent.

Clearly, evidence on the effectiveness of informal training is scarce given that it mostly pertains to developing countries, and also owing to the nature of the training per se, which relies on the informality of both the labor market and the training. Nonetheless, the few studies that have been identified inform on the selection problem we observed for the other types of training, and seem to indicate that informal training improves the labor market opportunities of the trainees. However, further research on evaluating traditional and informal apprenticeships is needed. 


\section{Conclusions from a Policy Perspective}

The research reviewed in this paper highlights the particular strengths and weaknesses of the three major distinct types of vocational education and training (VET). Beyond the core of general education, VET is a valued alternative, with the dual system seeming to be more effective than school-based VET. Informal training is effective, but not much is known concerning its relative strengths compared with other forms of vocational education.

On the one hand, school-based VET delivered at training centers at the post-compulsory secondary level, or as a specialization track during compulsory schooling, follows a formal curriculum combining general skills with occupation-specific education. Through the provision of technical skills, participation in school-based vocational education aims at a direct entry into the labor market, requiring only little on-the-job training by employers, and might hence be perceived as creating incentives for employer hiring. However, the success of the school-based training crucially depends on the alignment of skills taught in the schools to the labor market, and hence requires the close collaboration of employers, unions and the educational institutions. On the other hand, dual VET combines work place experience and training with school-based vocational education, usually within a particular occupation or sector of work. Well designed and effective dual training complements the rather firm-specific technical skills acquired by learning on-the-job within a training company with general skills that are transferrable across employers within the occupation. While practical work-experience within the firm is expected to provide higher returns for practically oriented youth, standardized curricula and central examinations are used to counteract overspecialization and low levels of transferability. Both training standards in firms and the alignment of skills taught in the schools and at the workplace have to be ensured through collaboration with the respective employers, unions and educational institutions.

Finally, informal VET enables a direct transition to work, generally leading to better pay in the short run compared to participation in vocational schooling, particularly in countries where these systems are marginal or outdated. However, as the acquisition of skills is restricted to learning on-the-job and is complete without systematic certification, this type of learning is likely to be of less value when moving jobs. Due to the lack of general skills and informal training in more modern occupations, employability is more limited and thus entails a higher risk of ending up in a vulnerable labor market position.

While dual VET may seem the best system to implement, international experiences show that attempts towards such schemes often fail. Dual VET - and VET in general - only works 
sustainably if there is significant institutional support and acceptance by major actors. For instance, dual VET can only be effective if employers engage with this type of structure and systematic training, and if training curricula are up to date. This requires the participation of employers in the design of training schemes, given that only they know their current and expected needs. Furthermore, VET only works if it is generally accepted as an attractive option for starting a career.

As can be seen from many examples in the developing world, some elements of (dual) VET can be implemented even under adverse conditions - and regional or sectoral training clusters can be established with sufficient support and interest from governments and employers. Most countries could therefore implement feasible or 'lighter' forms of dual VET with limited institutional requirements. Starting points could be existing sectoral or regional clusters of firms with a shared interest in a specifically skilled labor force in particularly relevant occupations, large (also foreign-owned) firms in modern sectors or sectoral training schemes run by employer associations. Where there is a basic agreement on training curricula and training provision, this can lead to mutually recognized certificates; public support would also be helpful, such as support for schooling phases and some non-bureaucratic regulation of training elements and standards in order to recognize acquired skills.

In many countries, strengthening the vocational part of the educational or schooling system and bringing existing vocational education and training systems closer to the current needs of the labor market would help young people with a smoother transition into work. In particular, vocational education provided in the framework of secondary schooling (vocational schools or vocational tracks) should be modernized and complemented with phases of practical work experience, such as internships or passing the final year with an employer. Employers should also be consulted regarding the design of vocational schooling curricula, which requires a systematic coordination with networks or associations of employers. Furthermore, in order to avoid a negative perception of vocational education as a dead-end option, transition to further education, including tertiary education, should be facilitated. Finally, reducing vocational education fees can help to raise enrollment in some countries. Moreover, in countries with high shares of university graduates having major difficulties in finding adequate jobs, one major option is to make academic training more labor market-oriented, incorporating internships with employers into academic curricula so that some experience with current work practices in the private sector can be acquired. Governments responsible for funding academic education can require public universities to modify academic curricula accordingly.

Providing better training for the informal sector represents a core issue for many developing 
countries. In countries where traditional or informal apprenticeships are dominant yet mainly confined to traditional crafts, these apprenticeships should be better articulated with the schooling system and formal sector. They should also be opened up to new technologies and occupational change, which requires some recognition of informal employment as part of the economic and social reality in many countries. A first option is to bring societal initiatives aimed at better training closer to the informal sector, family business and local networks. A concrete step could be to encourage informal workers and employers to participate in training activities, such as providing informal apprentices with some vocational schooling focusing on more general skills and theoretical aspects. Participation in vocational courses for young people working in the informal sector could be increased by providing incentives to participants and employers, particularly compensating for hours not worked due to training courses. To avoid deterrence, these courses should not be delivered directly by governments, but rather by NGOs, churches or non-profit associations with sufficient acceptance and in-depth knowledge of the economic situation in local communities. Involving larger employers or (formal) training centers is another option, with funding potentially coming from governments and international donors. NGOs, churches or other non-profit associations can also facilitate the creation of (informal) associations or networks of informal employers.

In addition, given that traditional or informal apprenticeships tend to be restricted to a number of traditional craft, raising productivity and potentials for innovation is crucial. Experiences from the African continent show that master craftsmen benefit from skill upgrading courses to better develop their businesses and become more innovative and productive. They also benefit from better access to technical equipment and capital, which should be made more easily accessible to informal firms. Furthermore, some experiences from Sub-Saharan Africa show that ensuring skill recognition outside the local community by some sort of official skill testing open to informal apprenticeship graduates raises the attractiveness of these training courses and enhances mobility on the job market.

\section{Table 1. Jóvenes Programs in Latin America}

1. Argentina: Proyecto Joven (Aedo and Nunes 2001): The non-experimental analysis based on propensity score matching shows a 10 percent increase in the employment probability of adult women (not of men) and a 10 percent increase in monthly wages for young males and adult females. 
2. Colombia, Jóvenes en Acción (Attanasio, Kugler and Meghir 2007): The experimental analysis shows an increase a substantial increase (18 to 35 percent) in earnings and a 5 percent increase in employment opportunities for both men and women, with larger results for women.

3. Dominican Republic, Joventud y Employ (Card et al. 2010): The experimental design finds no effect on employment probabilities, however finds a (marginally significant) 10 percent increase in wages.

4. Chile, Chile Joven (Aedo and Pizarro 2006): The non-experimental analysis based on propensity score matching shows a 21 percent increase in the employment probability of young women and a 26 percent increase in monthly wages, with best results for the young.

5. Peru, ProJoven (Díaz and Jaramillo 2006): The experimental analysis shows a 6 percent increase in employment probabilities and a 18 percent increase in hourly wages. 


\section{References}

Acemoglu, Daron, and Jorn- Steffen Pischke. 1998. "Why Do Firms Train? Theory And Evidence.” The Quarterly Journal of Economics 113(1): 78-118.

. 1999. “Beyond Becker: Training in Imperfect Labour Markets.”, Economic Journal 109(453): $112-42$

. 2000. “Certification of training and training outcomes.”, European Economic Review 44(4-6): 917-27.

Adams, Arvil Van. 2010. "The Mubarak Kohl Initiative - Dual System in Egypt. An assessment of its impact on the school to work transition."

Adda, Jerome, Christian Dustmann, Costas Meghir, and Jean-Marc Robin. 2011. "Career Progression and Formal versus On-the-Job Training.” Mimeo.

Aedo, Cristian, and Sergio Nunes. 2001. "The impact of training policies in Latin America and the Caribbean: the Case of Programa Joven”, ILADES and Georgetown University, May 2001.

Aedo, Cristian, and Marcelo Pizarro. 2004. "Rentabilidad económica del programa de capacitación laboral de jóvenes Chile Joven.” Mimeo.

AfDB, OECD, UNDP and UNECA. 2012. African Economic Outlook 2012: Promoting Youth Unemployment. OECD Publishing.

Aggarwal, Ashwani, Christine Hofmann, and Alexander Phiri. 2010. A study on informal apprenticeship in Malawi. Employment Sector Employment Report 9/2010. ILO, Geneva.

Ahadzie, William. 2009. "The Traditional Informal Apprenticeship System of West Africa as Preparation for Work.” In Rupert Maclean, David N. Wilson, eds., International Handbook of Education for the Changing World of Work, 261-75. Springer.

Alet, Elodie, and Liliane Bonnal. 2011. "Vocational schooling and educational success: comparing apprenticeship to full-time vocational high-school.” Mimeo.

Almeida, Rita, Jere Behrman, and David Robalino. 2012. "The right skills for the job?: Rethinking training policies for workers.” World Bank Publications, World Bank, Washington, DC.

Arulampalam, Wiji, Alison L. Booth, and Mark L. Bryan. 2004. “Training in Europe.” Journal of the European Economic Association 2(2-3): 346-60.

Atchoarena, David, and Andre Delluc. 2001. Revisiting Technical and Vocational Education and Training in Sub-Saharan Africa, IIEP Paris.

Attanasio, Orazio, Adriana Kugler, and Costas Meghir. 2011. "Subsidizing Vocational Training for Disadvantaged Youth in Colombia: Evidence from a Randomized Trial.” American Economic Journal 3(3): 188-220.

Bassanini, Andrea, Alison L.Booth, Giorgio Brunello, Maria De Paola, and Edwin Leuven. 2005. "Workplace Training in Europe.” IZA Discussion Papers 1640. Institute for the Study of Labor, Bonn, Germany. 
Bardak, Ummuhan. 2006. "An overview of educational systems and labour markets in the Mediterranean region.” Mediterranean Journal of Educational Studies 11 (1): 03-125.

Bartlett, Will. 2009. "The effectiveness of vocational education in promoting equity and occupational mobility amongst young people.” Economic Annals 54(180): 7-39.

Becker, Gary S..1964. "Human Capital: A Theoretical and Empirical Analysis, with Special Reference to Education”, University of Chicago Press, New York.

Bejaković, Predrag. 2004. "How prepared is Croatia for a knowledge-based society?” In Katarina Ott, ed., Croatian Accession to the European Union: Facing the challenges of negotiations, 109-28. Zagreb: Institute of Public Finance.

Bennell, Paul. 1996. “General versus Vocational Secondary Education in Developing Countries: A review of the rates of return evidence.” The Journal of Development Studies 33(2): 230-47.

Bennell, Paul , and Jan Sergerstrom. 1998. "Vocational education and training in developing countries: Has the World Bank got it right?” International Journal of Educational Development 18 (4): 271-87.

Bertschy, Kathrin, M. Alejandra Cattaneo, and Stefan C. Wolter. 2009. "PISA and the Transition into the Labour Market” Labour 23(Special Issue): 111-37.

Betcherman, Gordon, Martin Godfrey, Susana Puerto, Friederike Rother, and Antoneta Stavreska. 2007. "A review of interventions to support young workers: Findings of the youth employment inventory.” World Bank Social Protection Discussion Paper 0715.

Bilginsoy, Cihan. 2003. "The Hazards of Training: Attrition and Retention in Construction Industry Apprenticeship Programs.” Industrial and Labor Relations Review 57(1): 54-67.

Bishop, John H., and Ferran Mane. 2004. "The impacts of career-technical education on high school labor market success.” Economics of Education Review 23(4): 381-402.

BMBF (Bundesministerium für Bildung und Forschung). 2011. Datenreport zum Berufsbildungsbericht 2011. Informationen und Analysen zur Entwicklung der beruflichen Bildung. Bonn. Berlin, 2011.

Bonnal, Liliane, Sylvie Mendes, and Catherine Sofer. 2002. "School-to-work transition: apprenticeship versus vocational school in France.” International Journal of Manpower 23(5): 426-42.

Bukodi, Erzsébet, and Péter Róbert. 2011. "Education and labor market entry in transition: the case of Hungary.” In Irena Kogan, Clemens Noelke, and Michael Gebel, eds., Making the Transition. Education and labor market entry in Central and Eastern Europe. Stanford: Stanford University Press.

Card, David, Pablo Ibarrarán, Ferdinando Regalia, David Rosas-Shady, and Yuri Soares. 2011. "The Labor Market Impacts of Youth Training in the Dominican Republic." Journal of Labor Economics 29(2): 267-300.

CEDEFOP. 2008. Initial vocational education and training (IVET) in Europe: Review, European Centre for the Development of Vocational Training

CEDEFOP. 2010. Employer-provided vocational training in Europe 
CEDEFOP. 2011a. España, Una Mirada a la Formación Professional.

CEDEFOP. 2011b. VET in Europe - Country Report France.

Carrero Perez, Elena.2006. Reforming Technical and Vocational Education and Training in the Middle East and North Africa: Experiences and Challenges, European Training Foundation, Luxembourg.

Chung, Y. Peter. 1995. "Returns to vocational education in developing nations.” In Martin Carnoy, ed., International Encyclopaedia of Economics of Education. 175-81. Oxford: Pergamon.

CINTERFOR (Centro Interamericanopara el Desarollo del Conocimiento en la Formacion Professional). 2008. Recent evolution and future prospects for technical cooperation in vocational training in Latin America and the Caribbean. Discussion Paper prepared for the Technical Meeting Technical Cooperation in the Development of Vocational Training in Latin America and the Caribbean, Buenos Aires.

Cort, Pia. 2008. “The Danish Vocational Training and Education System.” $2^{\text {nd }}$ edition, Copenhagen.

Dearden, Lorraine. 1999. "Qualifications and earnings in Britain: how reliable are conventional OLS estimates of the returns to education?” IFS Working Papers W99/07. Institute for Fiscal Studies.

Dearden, Lorraine, Steven McIntosh, Michal Myck, and Anna Vignoles. 2002. "The Returns to Academic and Vocational Qualifications in Britain.” Bulletin of Economic Research 54(3): 249-74.

Dearden, Lorraine, Leslie McGranahan , and Barbara Sianesi. 2004. "An In-Depth Analysis of the Returns to National Vocational Qualifications Obtained at level 2.” CEE Discussion Papers 0046. Centre for the Economics of Education.

Denu, Berhanu, Abraham Tekeste, and Hannah van der Deijl. 2005. "Characteristics and determinants of youth unemployment, underemployment and inadequate employment in Ethiopia.” ILO Employment Policies Unit, Employment Strategy Paper 2005/07.

De Moura Castro, Claudio, and Aimee Verdisco. 1998. "Training Unemployed Youth in Latin America: Same Old Sad Story?” Inter-American Development Bank. Washington D.C.

DFID (Department for International Development). 2007. Technical and vocational skills development. Briefing.

Díaz, Juan José, and Miguel Jaramillo. 2006. "Evaluation of the Peruvian "Youth Labor Training Program - ProJoven".” Working Paper October. Grupo de Analisis para el Desarrollo. GRADE. Lima.

Dionisius, Regina, Samuel Mühlemann, Harald Pfeifer, Guenter Walden, Felix Wenzelmann, and Stefan C. Wolter. 2009. "Costs and benefits of apprenticeship training. A comparison of Germany and Switzerland.” Applied Economics Quarterly 55 (1): 5-38.

Dustmann, Christian, and Uta Schönberg. 2009. “Training and Union Wages.” The Review of Economics and Statistics 91(2): 363-76.

. 2012. "What Makes Firm-Based Vocational Training Schemes Successful? The Role of Commitment.” American Economic Journal: Applied Economics 4(2): 36-61.

Ebner, Christian. 2009. "Neue Wege für die duale Berufsausbildung- Ein Blick auf Österreich, die Schweiz und Dänemark.” WZB Brief Arbeit Nr. 4. 
Foster, Philip., 1965. The vocational school fallacy in development planning. In: Anderson, A.A., Bowman, M.J. (Eds.), Educationand Economic Development. Aldine, Chicago.

Felgueroso, Florentino., 2010. Reforma Laboral y Empleo Juvenil, El Comercio.es 25 June.

Garcia, Marito, and Jean Fares. 2008c. "The Effect of Education on Income and Employment.” In Marito Garcia and Jean Fares, eds., Youth in Africa’s Labor Market, 39-47. World Bank.

Goerlitz, Katja, and Joel Stiebale. 2008. "Does product-market competition decrease employers' training investment? - Evidence from German establishment panel data.” Ruhr Economic Paper No. 41.

Goldin, Claudia. 2001. "The Human Capital Century and American Leadership: Virtues of the Past.” NBER Working Papers 8239. National Bureau of Economic Research, Inc.

Guarcello, Lorenzo, Scott Lyon, and Furio Rosati. 2008. "Child Labor and Youth Employment in Ethiopia.” In Marito Garcia and Jean Fares, eds., Youth in Africa’s Labor Market, 181-223. World Bank.

Hall, Caroline. 2012. "The Effects of Reducing Tracking in Upper Secondary School: Evidence from a Large-Scale Pilot Scheme.” Journal of Human Resources 47(1): 237-69.

Haltiwanger, John, and Manisha Singh. 1999. "Cross-Country Evidence on Public Sector Retrenchment.” World Bank Economic Review. World Bank Group 13(1): 23-66.

Hanushek, Eric A., Ludger Woessmann, and Lei Zhang. 2011. "General Education, Vocational Education and Labor Market Outcomes over the Life-Cycle.” IZA Discussion Paper 6083.

Heynemann, Stephen P.. 1997. "The quality of education in the Middle East and North Africa (MENA).” International Journal of Educational Development 17(4): 449-66.

Heckman, James. 1993. “Assessing Clinton's Program on Job Training, Workfare, and Education in the Workplace.” National Bureau of Economic Research.Working Paper, Nr. 4428.

Hippach-Schneider, Ute, Kristina Hensen, and Karen Schober. 2011. "VET in Europe - Country Report in Germany.” Federal Institute For Vocational Education and Training. BIBB, Bonn.

Holsinger, Donald B, and Richard Cowell. 2000. "Positioning Secondary-School Education in Developing Countries: Expansion and Curriculum.” In Policies \& Strategies for Secondary Education, International Institute for Educational Planning, UNESCO.

Hoeckel, Kathrin. 2008. “Costs and Benefits in Vocational Education and Training.” OECD Education.

Hoeckel, Kathrin, and Robert Schwartz. 2010. "Learning for Jobs- OECD Reviews of Vocational Education and Training:Germany.” OECD.

Hotchkiss, Lawrence. 1993. "Effects of Training, Occupation, and Training-Occupation Match on Wage.” Journal of Human Resources 28(3): 482-496. 
Ibarrarán, Pablo, and David Rosas Shady. 2009. "EvaluatingtheImpact of Job Training Programs in Latin America: Evidence from IDB funded operations.” Journal of Development Effectiveness 1(2): 195-216.

Ibw (Institut zur Bildungsforschung der Wirtschaft). 2009. Die Lehre. Duale Berufsausbildung in Österreich. Bundesministerium für Wirtschaft, Familie und Jugend. Wien.

ILO. 2010. Trabajo Decente y Juventud en América Latina, Avance, February.

ILO. 2011. Upgrading Informal Apprenticeship Systems, ILO Policy Brief.

ILO. 2012. Upgrading informal apprenticeship, A resource guide for Africa. ILO.

Kahyarara, Godius, and Francis Teal. 2008. "The Returns to Vocational Training and Academic Education: Evidence from Tanzania.” World Development 36(11): 2223-42.

Kammermann, Marlise, Barbara E., and Achim Hättich. 2011. “Two-year apprenticeships - a successful model of training?” Journal of Vocational Education and Training 63(3): 37796.

Katz, Eliakim, and Adrian Ziderman. 1990. "Investment in General Training: The Role of Information and Labour Mobility.” Economic Journal 100(403): 1147-58.

King, Kenneth. 2011. "Eight Proposals For a Strengthened Focus on Technical and Vocational Education and Training (TVET) in the Education for All (EFA) Agenda." Background paper prepared for the Education for All Global Monitoring Report 2012.

King, Kenneth, and Chris Martin. 2002. "The vocational school fallacy revisited: education, aspiration and work in Ghana 1959-2000.” International Journal of Educational Development 22: 5-26.

King, Kenneth, Simon McGrath, and Pauline Rose, P, 2007. "Beyond Basic Education and Towards an Expanded Vision of Education - for Poverty Reduction and Growth?” International Journal of Educational Development 27(4): 349-57.

Kogan, Irena. 2008. “Educationsystems of Central and Eastern European countries.” In Irina Kogan, Michael Gebel, and Clemens Noelke, eds., Europe enlarged: A handbook of education, labour and welfare regimes in Central and Eastern Europe. Bristol: The Policy Press.

Krueger, Dirk, and Krishna B. Kumar. 2004. "Skill-specific rather than general education: A reason for US-Europe Growth Differences?” Journal of Economic Growth 9:167-207.

Lahire, Nathalie, Richard Johanson, and Ryoko Tomita Wilcox. 2011. "Youth Employment and Skills Development in the The Gambia.” Working Paper 217. Work Bank, Policy Research Department, Washington, DC.

Lazear, Edward P.. 2003. Firm-specific human capital: A skill-weights approach. NBER Working Paper W9679.

Lerman, Robert I., and Felix Rauner. 2012. “Apprenticeships in the United States.” In Antje Barabasch, and Felix Rauner, eds., Work and Education in America, 175-93.

Malcomson, James M., James W. Maw, and Barry McCormick. 2003. "General training by firms, apprentice contracts, and public policy.” European Economic Review 47(2): 197-227. 
Mane, Ferran. 1999. "Trends in the payoff to academic and occupation-specific skills: the short and medium run returns to academic and vocational high school courses for non-college-bound students.” Economics of Education Review 18(4): 417-37.

Masson, Jean-Raymond, Mounir Baati, and Erwin Seyfried. 2010. “Quality and Quality Assurance in Vocational Education and Training in Mediterranean Countries: Lessons from the European Approach.” European Journal of Education 45(3): 514-26.

Matkovic, Teo. 2008. "Recent developments in the education system and school-to-work transitions in Croatia.” Working Paper 138. Mannheimer Zentrum für Europäische Sozialforschung.

McCormick, Alexander C., Tuma, John, Houser, James. 1995. Vocational Course Taking and Achievement. Statistical Analysis Report.National Center for Education Statistics.

Meer, Jonathan. 2007. "Evidence on the returns to secondary vocational education.” Economics of Education Review 26(5): 559-73.

Micklewright, John. 1999. “Education, inequality and transition.” Economics of Transition 7(2): 343-376.

Middleton, John, Adrian Ziderman, and Arvil V. Adams. 1993. "Skills for Productivity: Vocational Education and Training in Developing Countries.” New York: Oxford University Press.

Moenjak, Thammarak, and Christopher Worswick. 2003. "Vocational education in Thailand: a study of choice and returns.” Economics of Education Review 22(1): 99-107.

Mohrenweiser, Jens, and Thomas Zwick. 2009. "Why do firms train apprentices? The net cost puzzle reconsidered.” Labour Economics 16 (6): 631-37.

Monk, Courtney, Justin Sandefur, and Francis Teal. 2008. "Does Doing an Apprenticeship Pay Off? Evidence from Ghana.” CSAE Working Paper Series 2008-08, Centre for the Study of African Economies, University of Oxford.

Neuman, Shoshana, and Adrian Ziderman. 1999. "Vocational Education in Israel: Wage Effects of the VocEd-Occupation Match.” The Journal of Human Resources 34 (2): 407-20.

Newhouse, David, and Daniel Suryadarma. 2011. "The Value of Vocational Education: High School Type and Labor Market Outcomes in Indonesia.” World Bank Economic Review 25(2): 296-322

Noelke, Clemens, and Daniel Horn. 2011. "Social Transformation and the Transition from Vocational Education to Work.” Budapest Working Papers on the Labour Market 2011/5.

Nübler, Irmgard, Christine Hofmann, and Clemens Greiner. 2009. "Understanding informal apprenticeship: Findings from empirical research in Tanzania.” Employment Sector Employment Working Paper 32/2009, ILO.

OECD. 2012. Employment Outlook, United Kingdom, OECD Publishing, Paris.

Oketch, Moses O.. 2007. "To vocationalise or not to vocationalise?, Perspectives on current trends and issues in technical and vocational education and training (TVET) in Africa." International Journal of Education Development 27(2): 220-34.

Oosterbeek, Hessel, and Dinand Webbink. 2007. "Wage effects of an extra year of basic vocational education.” Economics of Education Review 26(4): 408-19. 
Ost, David. 2000. "Illusory Corporatism in Eastern Europe: Neoliberal Tripartism and Postcommunist Class Identities.” Politics\& Society 28 (4), pp. 503-30.

Palmer, Robert. 2009. “Formalizing the informal: Ghana’s National Apprenticeship Programme. Journal of Vocational Education and Training 61 (1): 67-83.

Parey, Matthias. 2009. "Vocational Schooling versus Apprenticeship Training- Evidence from Vacancy Data.” Mimeo.

Pischke, Jorn Steffen, and Till von Wachter. 2008. "Zero Returns to Compulsory Schooling in Germany: Evidence and Interpretation.” The Review of Economics and Statistics 90(3): 592-98.

Planas, Jordi. 2005. "Vocational training in Spain: Changes in the model of skill production and management modalities.” Working Paper of the Universitat Autónoma de Barcelona.

Plug, Erik, and Wim Groot. 1998. "Apprenticeship versus vocational education: Exemplified by the Dutch Situation.” unpublished manuscript.

Psacharopoulos, George. 1973. "Returns to Education: An International Comparison.” Amsterdam: Elsevier; San Francisco: Jossey-Bass.

. 1985. "Returns to Education: A Further International Update and Implications.” Journal of Human Resources 20(4): 583-604.

. 1987. "Public versus private schools in developing countries: Evidence from Colombia and Tanzania.” International Journal of Educational Development 7 (1): 59-67.

. 1994. "Returns to investment in education: A global update.” World Development, Elsevier 22(9): 1325-43.

Psacharopoulos, George, and Wiliam A. Loxley. 1985. "Diversified Secondary Education and Development: Evidence from Colombia and Tanzania.” Baltimore: Johns Hopkins University Press.

Puerto, Olga Susana. 2007. "Interventions to Support Young Workers in Latin America and the Caribbean.” Regional Report for the Youth Employment Inventory. World Bank.

Quintini, Glenda, and Sebastien Martin. 2006. "Starting well or losing their way? The position of youth in the labour market in OECD countries.” OECD Social, Employment and Migration Working Papers 39, Paris.

Quintini, Glenda, John P. Martin, and Sebastien Martin. 2007. "The Changing Nature of the Schoolto-Work Transition Process in OECD Countries.” IZA Discussion Paper 2582.

Quintini, Glenda, and Thomas Manfredi. 2009. “Going Separate Ways? School-to-Work Transitions in the United States and Europe.” OECD Social, Employment and Migration Working Paper 90.

Rioust de Largentaye, Armand Rioust. 2009. VET and the Informal Economy.

Robinson, Peter. 1997. "The Myth of Parity of Esteem: Earnings and Qualifications.” Discussion Paper 354, London School of Economics: Centre for Economic Performance.

Roger, Muriel, and Philippe Zamora. 2011. Hiring young unskilled workers on subsidized openended contracts: A good integration programme? Oxford Review of Economic Policy 27(2): 380- 
396.

Saar, Ellu, Marge Unt, and Irena Kogan. 2008. "Transition from Educational System to Labour Market in the European Union: A Comparison between New and Old Members.” International Journal of Comparative Sociology 49(1): 31-59.

Schlotter, Martin, Guido Schwerdt, and Ludger Woessmann. 2011. "Econometric methods for causal evaluation of education policies and practices: a non-technical guide.” Education Economics 19(2): 109-137.

Shapiro, Daniel. 1999. "School-to-work partnerships and employer participation: evidence on persistence and attrition from the National Employer Survey.” National Center for Postcompulsory Improvement.

Shavit, Yossi, and Walter Müller. 1998. "From School to Work: A Comparative Study of Educational Qualifications and Occupational Destinations.” Oxford: Clarendon Press.

. 2000. “Vocational Secondary Education.” European Societies 2(1): 29-50.

Smits, Wendy. 2007. "Industry-specific or generic skills? Conflicting interest of firms and workers." Labour Economics 14(3): 653-63.

Sondergaard, Lars, and Mamta Murthi. 2012. "Skills, Not Just Diplomas- Managing Education for Results in Eastern Europe and Central Asia.” World Bank.

Tansel, Aysit. 1994. "Wage employment, earnings and returns to schooling for men and women in Turkey.” Economics of Education Review 13 (4): 305-320.

. 1999. "GeneralversusVocationalHighSchoolsandLaborMarketOutcomesin Turkey.” Economic Research Forum Working Paper No. 9905.

Tattara, Giuseppe, and Marco Valentini. 2009. "Can employment subsidies and greater labour market flexibility increase job opportunities for youth? Revisiting the Italian On-the-job Training Programme.” Business and Economics 42(3): 197-212.

Tuma, John. 1994. "Measuring Enrollment and Participation in Secondary Vocational Education With High School Transcript Records.” Journal of Vocational Education Research 19 (3): 3-22.

Tunali, Insan. 2003. “General vs. Vocational Secondary School Choice and Labor Market Outcomes in Turkey 1988-98.” Mimeo.

Vlaardingerbroek, Barend, and Yasmin Hachem El-Masri. 2008. "Student transition to upper secondary vocational and technical education (VTE) in Lebanon: from stigma to success.” Journal of Vocational Education\& Training 60(1): 19-33.

Walther, Richard. 2011.Building Skills in the Informal Sector. Background paper prepared for the Education for All Global Monitoring Report 2012, UNESCO.

Weller, Jürgen. 2009. Regulation, worker protection and active labour-market policies in Latin America, United Nations, Economic Commission for Latin America and the Caribbean.

Willis, Robert J., and Sherwin Rosen. 1979. "Education and Self-Selection.” The Journal of Political Economy 87(5): 7 -36. 
Winkelmann, Rainer. 1996. "Employment prospects and Skill Acquisition of Apprenticeship- Trained Workers in Germany.” Industrial and Labour Relations Review 49(4): 658-72.

Woessmann, Ludger. 2008. "Efficiency and Equity of European education and training policies.” International Tax and Public Finance 15(2): 199 -230.

Wolter, Stefan C., and Jüri Schweri. 2002. "The cost and benefit of apprenticeship training: The Swiss case.” Applied Economics Quarterly 48 (1-2): 347-67.

Wolter, Stefan C., and Paul Ryan. 2011. “Apprenticeship.” In Eric Hanushek, Stephen Machin and Ludger Woessmann, ed., Handbook of Economics of Education 3(3), Elsevier.

World Bank. 2004. “MENA Development Report.” Unlocking the Employment Potential in the Middle East and North Africa. Washington DC.

World Bank. 2005. "Expanding Opportunities and Building Competencies for Young People: A New Agenda for Secondary Education.” Washington, DC. 